\title{
Promising medicinal plants their parts and formulations prevalent in folk medicines among ethnic communities in Madhya Pradesh, India
}

\begin{abstract}
India is a resipository of medicinal plants rich in herbal treasure and floristic wealth. Plants are being used since ancient times as a source of drugs as depicted from Indian ancient Hindu scriptures like Rigveda (4500-1600 BC), Charak samhita (1000-800 BC), Sushrut Samhita (800-700 BC). The medicinal plants play an important role in folk-medicines among 104.2million ethnic communities inhabited in 5000 villages in India where no such modern facilities of hospitals exits, and also plays a significant role in socio-cultural, spiritual, health needs of communities, across the globe in developing and developed countries. Gradually, $85 \%$ of the herbal and folk-medicines are derived from plants on which 4.3 billion people rely, across the globe. In Indian sub-continent folk-medicines are still prevalent among $25.2 \%$ of ethnic community in Madhya Pradesh are inhabited in $15 \%$ of the total geographical population of the country, who had accumulated a great amount of knowledge on use of plants. The paper precisely depicts some of the promising plants prevalent in Ethnic pockets viz. Chhatarpur, Satna, Jabalpur, Seoni, Chhindwara and Hoshanagabad districts in Madhya Pradesh in India.
\end{abstract}

Keywords: medicinal plants, herbal treasure, floristic wealth, drugs, hindu scriptures, folk-medicines, ethnic communities, artharva veda, charak, sushrita, tribal communities, gond, baiga, bhariya, bhil, bhilala, korku, kol, bediya, pardhi, khairwar, sahariya
Volume 5 Issue 3 - 2017

\author{
Rajiv Rai \\ Scientist F, Indian Council of Forestry Research and Education, \\ Tropical Forest Research Institute, India
}

Correspondence: Rajiv Rai, Scientist F, Indian Council of Forestry Research and Education, Tropical Forest Research Institute, India, Tel +9l 9479644205, Email rai_rajiv_57@hotmail.com

Received: April 24, 2017| Published: May 12, 2017

\section{Introduction}

India has a rich knowledge on plant based drugs both for use in preventive and curative medicines. The classical work of the "Artharva Veda", many ancient Indian Scholars like "Charak" "Sushrita" and others had played a vital role in describing Indian medicinal Plants. The history of herbal medicines in India is thus very old, perhaps the oldest use of plants in herbal medicine had been documented in Hindu scriptures like Rigveda (4500-1600 B.C.), Charak Samhita (6 $6^{\text {th }}-2^{\text {nd }}$ century BC), Atharvaveda (200 BCE-1000 BCE) who are known to had accumulated a great amount of knowledge on use of various plant species. The ethnic communities comprises of Gond, Baiga, Bediya, Bhil, Bhilala, Bhariya, Korku, Pardhi tribes been reported to be used in Indian sub-continent, but 500 of them are most commonly employed by different ethnic communities prevailing in the country. ${ }^{1}$ The Indian sub-continent is inhabited by large number of ethnic communities and they live in forest and forest fringe areas..$^{2-7}$ The Indian state of Madhya Pradesh $22.9734^{\circ} \mathrm{N}, 78.6569^{\circ} \mathrm{E}$ wherein the present study has been carried out, is inhabited by various tribal communities, who are known to have accumulated a vast knowledge on use of various plant species. The review of literature reveal's that much work has been done on ethno-medicinal plants in Madhya Pradesh along with the documentation of floristic study and herbal medicines carried out by numerous ethnobotanist's. ${ }^{8-22,25-32,34-38,40}$ but still there are some interior areas with pre-dominance of ethnic communities which need to be intensively surveyed.

\section{Materials and methods}

\section{Study site}

The present study had been carried out in state of Madhya Pradesh in India, lies between latitude $17^{\circ} 48^{\prime} \mathrm{N}$ and $26^{\circ} 52^{\prime} \mathrm{S}$ and between longitude $74^{\circ} 2^{\prime} \mathrm{N}$ to $84^{0} 24^{\prime} \mathrm{E}$ in state of Madhya Pradesh; where by large number of tribal communities with wide diversity in ethnic races viz. Gond, Baiga, Bhariya, Bhil, Bhilala, Korku, Kol, Bediya, Pardhi, Khairwar, Sahariya etc. Ethno-medicinal data was collected in during survey conducted between theyears 2013-2016 in six tribal dominated districts of Jabalpur, Seoni, Chhattarpur Satna, Hoshangabad and Chhindwara in states of Madhya Pradesh, India between 2013 September to 2016 February

\section{Data collection}

The present investigation was carried out during 2013 September to 2016 February and data was collected from six clusters as shown in Figure 1. The study was conducted by interviews followed by focus group discussions with local indigenous communities. During the visits a number of traditional herbal healers and, elderly persons of tribal communities, were contacted and information was collected through interview, observations and discussion held during field survey. These medicinal plants were collected from wild. The local traditional herbal healers (vaids) had specialized knowledge about availability of these plants (trees, shrubs, herbs, and climbers) as well as their seasonal availability and time of collection for roots, leaves, seeds and fruits in cure of various ailments and preparation of herbal formulations.

\section{Interview with informants of knowledge}

The informants were asked about ethno-botanical uses from 25 respondents habitat in districts of Jabalpur, Seoni, Chhattarpur, Satna, Hoshanagabad and Chhindwada comprising of local vaidraj, traditional healers for 25 ailments and prescription presented in Table 
1 for the ethno-botanical data (Local name of plant, Family, plant part used, formulation in medicine in cure of ailments were recorded for descriptive response. Moreover, these findings indicate awareness about folk medicines prevalent among ethnic communities in different tribal localities. The information is presented in Table 1.

Table I Cure of ailments from herbal folk medicines prevalent among ethnic communities in MP

\begin{tabular}{|c|c|c|c|c|c|c|c|c|}
\hline S.No & Disease & Medicinal plant & $\begin{array}{l}\text { Local } \\
\text { name }\end{array}$ & Family & $\begin{array}{l}\text { Plant } \\
\text { category }\end{array}$ & $\begin{array}{l}\text { Plant } \\
\text { part }\end{array}$ & Formulation & Locality \\
\hline & \multirow{2}{*}{ Arthritis } & Vitex negundo Linn. & Nirgundi & Verbenaceae & Shrub & Leaf & Oil & $\begin{array}{l}\text { Turkakhapa, } \\
\text { Hoshangabad }\end{array}$ \\
\hline & & $\begin{array}{l}\text { Celastrus paniculata } \\
\text { Willd. }\end{array}$ & Malkangni & Celastraceae & Climber & Seed & Oil & $\begin{array}{l}\text { Majghganwan, } \\
\text { Satna. }\end{array}$ \\
\hline & \multirow{2}{*}{ Asthma } & $\begin{array}{l}\text { Abelmoschus } \\
\text { esculentus Linn. }\end{array}$ & Vanbhindi & Malvaceae & Shrub & Seed & Decoction & $\begin{array}{l}\text { Nibhora, } \\
\text { Jabalpur. }\end{array}$ \\
\hline & & $\begin{array}{l}\text { Zingiber purivren } \\
\text { Willd. }\end{array}$ & Jangali adrak & Zingiberaceae & Herb & Rhizome & Paste & $\begin{array}{l}\text { Mandikoh, } \\
\text { Hoshanagabad }\end{array}$ \\
\hline & \multirow{2}{*}{ Baldness } & $\begin{array}{l}\text { Adhatoda vasica } \\
\text { Nees }\end{array}$ & Adusa & Acanthaceae & Herb & Stem & Paste & $\begin{array}{l}\text { Satai, } \\
\text { Chhattarpur }\end{array}$ \\
\hline & & $\begin{array}{l}\text { Ecilipta alba (Linn.) } \\
\text { Hassr. }\end{array}$ & Bhringraj & Asteraceae & Herb & Leaf & Paste & Baldeogoan, Satna. \\
\hline & $\begin{array}{l}\text { Blood } \\
\text { Pressure }\end{array}$ & $\begin{array}{l}\text { Terminalia arjuna } \\
\text { (Roxb.) Wgt \& Arn. }\end{array}$ & Arjun & Combreataceae & Tree & Bark & Decoction & $\begin{array}{l}\text { Kundam, } \\
\text { Jabalpur }\end{array}$ \\
\hline & \multirow{2}{*}{ Bronchitis } & $\begin{array}{l}\text { Embelia ribes } \\
\text { Burm.f. }\end{array}$ & Vaividang & Myrsinaceae & climber & Root & Paste & $\begin{array}{l}\text { Banjari, } \\
\text { Seoni }\end{array}$ \\
\hline & & Lygodium Spps. & $\begin{array}{l}\text { Choti } \\
\text { Bhulan }\end{array}$ & Lygodiaceae & & Root & Powder & $\begin{array}{l}\text { Dhuma, } \\
\text { Seoni }\end{array}$ \\
\hline & \multirow{2}{*}{ Cancer } & Grewia hirsuta Vahile & Gursakri & Tiliaceae & Shrub & $\begin{array}{l}\text { Whole } \\
\text { Plant }\end{array}$ & Powder & $\begin{array}{l}\text { Chhapara, } \\
\text { Seoni }\end{array}$ \\
\hline & & Grewia tilifolia Vahile & Dhaman & Tiliaceae & Tree & Bark & Powder & Banjari ,Seoni \\
\hline & Dysentry & $\begin{array}{l}\text { Litsea glutinosa } \\
\text { (Lour)Rob. }\end{array}$ & Maida lakdi & Lauraceae & Tree & Bark & Powder & $\begin{array}{l}\text { Gwari, } \\
\text { Jabalpur. }\end{array}$ \\
\hline & \multirow[b]{2}{*}{ Fracture } & $\begin{array}{l}\text { Cuscuta reflexa } \\
\text { Roxb }\end{array}$ & Amarbel & Convolvulaceae & Climber & Panchang & Paste & Banjari ,Seoni \\
\hline & & $\begin{array}{l}\text { Cissus } \\
\text { quandrangularis } \\
\text { Linn. }\end{array}$ & Hadjodi & Vitacea & Climber & Stem & Paste & $\begin{array}{l}\text { Chitrakoot, } \\
\text { Satna }\end{array}$ \\
\hline & \multirow{2}{*}{ Jaundice } & $\begin{array}{l}\text { Cypersus scarious } \\
\text { R.Br. }\end{array}$ & Gundla & Cyperaceae & Herb & Root & Powder & $\begin{array}{l}\text { Patalkot, } \\
\text { Chhindwara. }\end{array}$ \\
\hline & & $\begin{array}{l}\text { Boerhaviaa diffusa } \\
\text { Linn. }\end{array}$ & Punarnava & Nyctaginaceae & Herb & Panchang & Powder & $\begin{array}{l}\text { Majghganwan, } \\
\text { Satna. }\end{array}$ \\
\hline & \multirow{2}{*}{ Headache } & $\begin{array}{l}\text { Ocimum sanctum } \\
\text { Linn. }\end{array}$ & Tulsi & Lamiaceae & Herb & Leaf & Paste & Pondi,Jabalpur \\
\hline & & $\begin{array}{l}\text { Achyranthus asper } \\
\text { Linn. }\end{array}$ & Apamarg & Amarathaceae & Herb & Root & Paste & $\begin{array}{l}\text { Kishangarh } \\
\text { Chhatarpur }\end{array}$ \\
\hline & \multirow{2}{*}{ Joint Pain } & $\begin{array}{l}\text { Curcma amada } \\
\text { Roxb. }\end{array}$ & Ama Haldi & Zingiberaceae & Herb & Rhizome & Paste & $\begin{array}{l}\text { Patalkot, } \\
\text { Chhindwara }\end{array}$ \\
\hline & & $\begin{array}{l}\text { Jatropha curcus } \\
\text { Linn. }\end{array}$ & Ratanjot & Euphorbiaceae & Shrub & Seed & Oil & $\begin{array}{l}\text { Kishangarh, } \\
\text { Chhatarpur. }\end{array}$ \\
\hline
\end{tabular}


Table Continued..

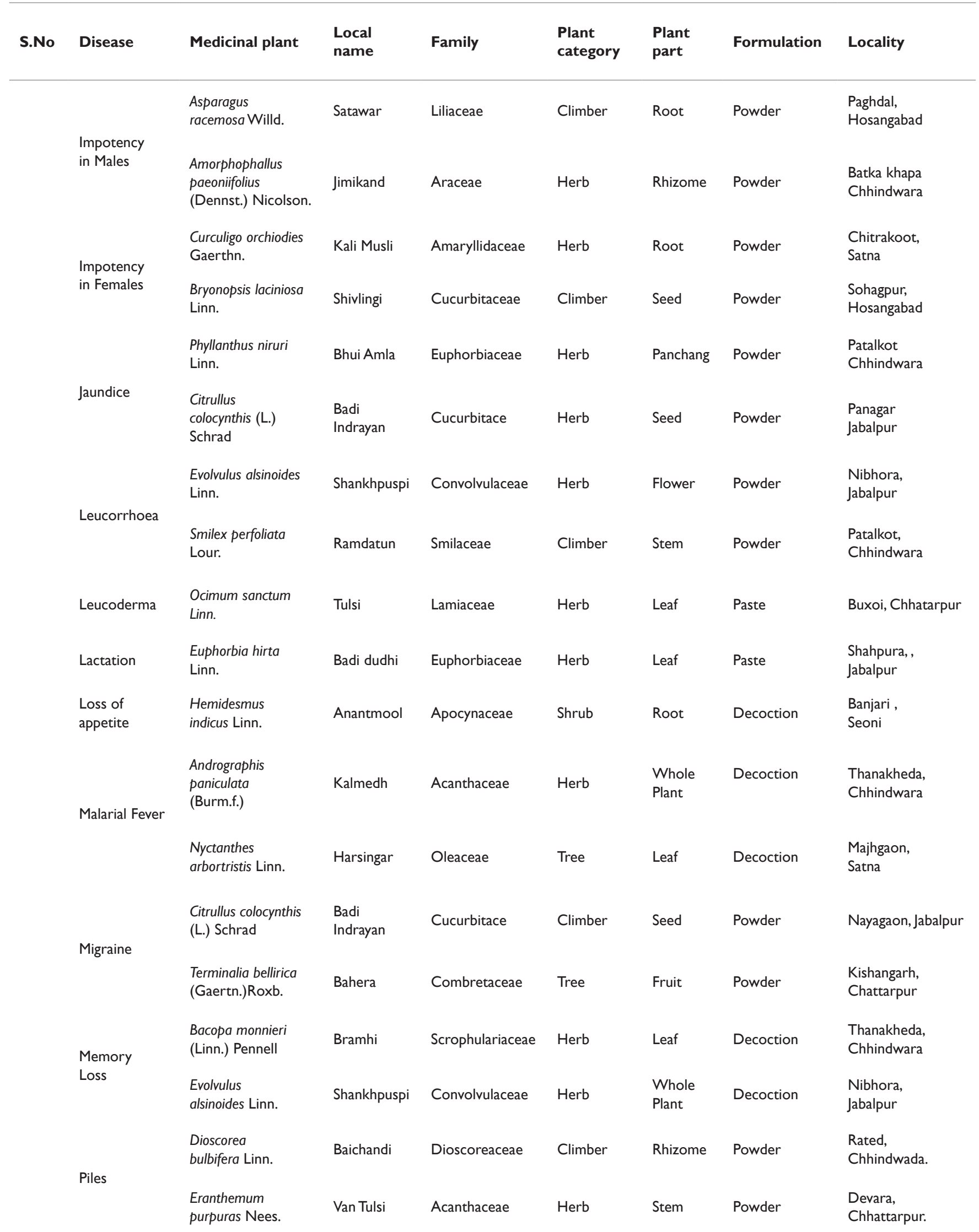


Table Continued.

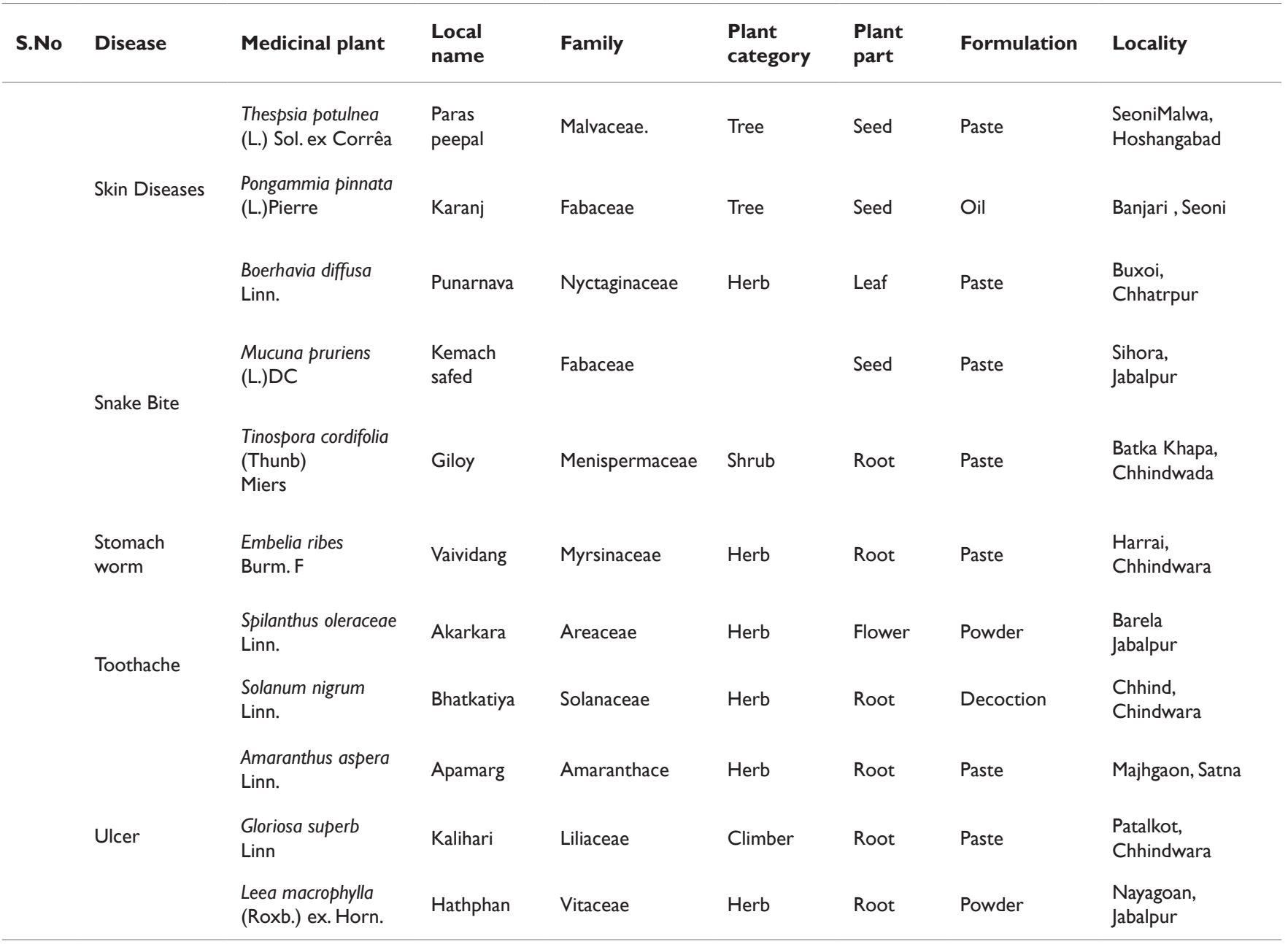

\section{Results and discussion}

The Ethno-medicinal survey was conducted in six districts of Madhya Pradesh, India which are having predominance of ethnic communities as shown in Figure 1. The study reveals that a large number of traditional healers (Vaidraj) belonging to different ethnic communities residing in different pockets of Madhya Pradesh are utilizing medicinal plant and their parts collected from herbs, shrubs, climbers and trees comprising from different plant families (Figure 2). The information was recorded from 25 traditional healers and elderly persons of ethnic communities belonging to Gond, Bhariya, Korku, Pardhi, Bhilala, Bediya and Kol tribes on 49 plant species with 54 uses of plants and their parts in different formulations such as powder, paste, decoction, extract, oil, raw and cooked parts of root, leaf, stem, whole plant (panchang), rhizome, bark and flower (Figure 4) used in cure of ailments viz. Arthiritis, Asthma, Baldness, Bronchitis, Cancer, Joint Pain, Dysentry, Fracture, Headache, Jaundice, in cure of Impotency in males and females, Leucorrhoea, Leucoderma, Loss of appetite, Malarial fever, Migraine, Memory loss, Piles, Skin infection/disease, Snake-bite, Stomach worms, Tooth-ache and Ulcer as presented in Table $1 \&$ Figure 3. The plant species listed are found in abundance in forest eco-system.

The study revealed medicinal plants and their parts as rhizome, root, stem, leaves, seeds, fruits flower, and bark of trees, herbs, shrubs and climbers are used in preparation of formulations viz. powder, paste, decoction, oil, raw edible and roasted forms (Figure 2) (Figure 4) are being used by traditional healers and vaidraj. They have vast knowledge about plants available in and around their habitat and plant parts used in preparation of different formulation, dosages and mode of administration (Figure 3 ) in primary health care of localities in dense forest.

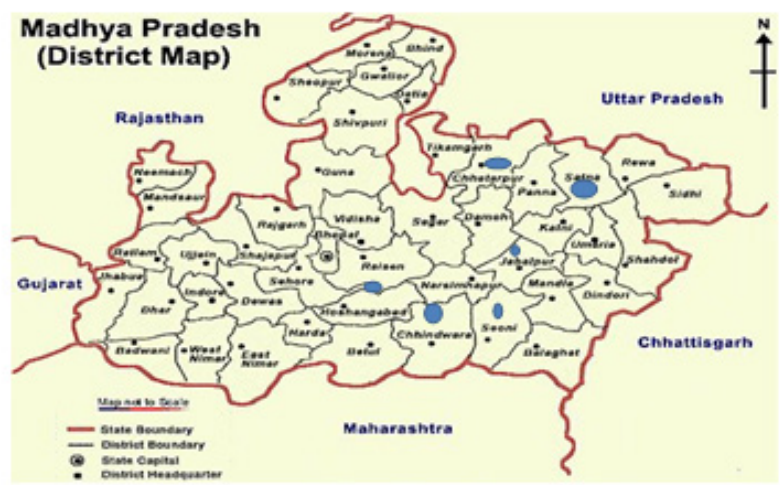

Figure I Study districts: Chhatarpur, Satna, Jabalpur, Seoni, Chhindwara \& Hoshanagabad. 
The results of plants used, formulations and dosages were different and not previously reported in any similarly conducted studies to document ethno-medicinal uses. As it is very clear from literature reviewed that different plant species were used in different tribal pockets of Madhya Pradesh like Gond tribes in Sagar district, ${ }^{8}$ Kol tribes in Rewa district, ${ }^{9}$ Baiga and Gond tribes in Mandla district in MP, ${ }^{11-14}$ Bheel tribes in Guna district ${ }^{23,24}$ Chambal eco-region ${ }^{22}$ and Bhil tribes in Jhabua district, ${ }^{24}$ Sahariya and Baiga primitive and other tribes in Madhya Pradesh, ${ }^{25-33}$ Gond, Bhriya and Korku tribes of Madhya Pradesh, ${ }^{28,29}$ Bheel tribes in Jhabua district ${ }^{41}$ in Khargone districts, ${ }^{42}$ Bhilala tribes in Alirajpur district, ${ }^{43}$ Sahariya tribe in Guna district. $^{44}$

The medicinal plants and their parts to cure ailments were documented (Figure 3) are used to prepare various formulations are prevalent since hundreds ofyears and are orally communicated from one generation to another, the discussions with local healers and villagers further revealed that the preferences in species to cure of ailments vary from one species to another species as a number of plants are used in cure of a particular ailment and the species, plant part used, formulation such as powder, paste, decoction, extract also vary from village to village in different tribal pockets, based on the ethnic culture and seasonal availability of medicinal plants as presented in Table 1. Based on the findings of present study, it has been found that tribal communities had rich knowledge on herbal folk medicines and distribution of plants around their habitat and used by them in cure of various ailments, and this vital knowledge is transmitted from one generation to another through oral communication as reported by. ${ }^{6,8,10,14,21,22,25-32,36,39,40}$ The villagers use different forest plant species in their daily life. Documentation of such information's is useful for further generation as well as for their daily life. Hence due to changing life style detailed study of ethno-botanical studies became necessary to document traditional knowledge as it is at the stage of disappearance.

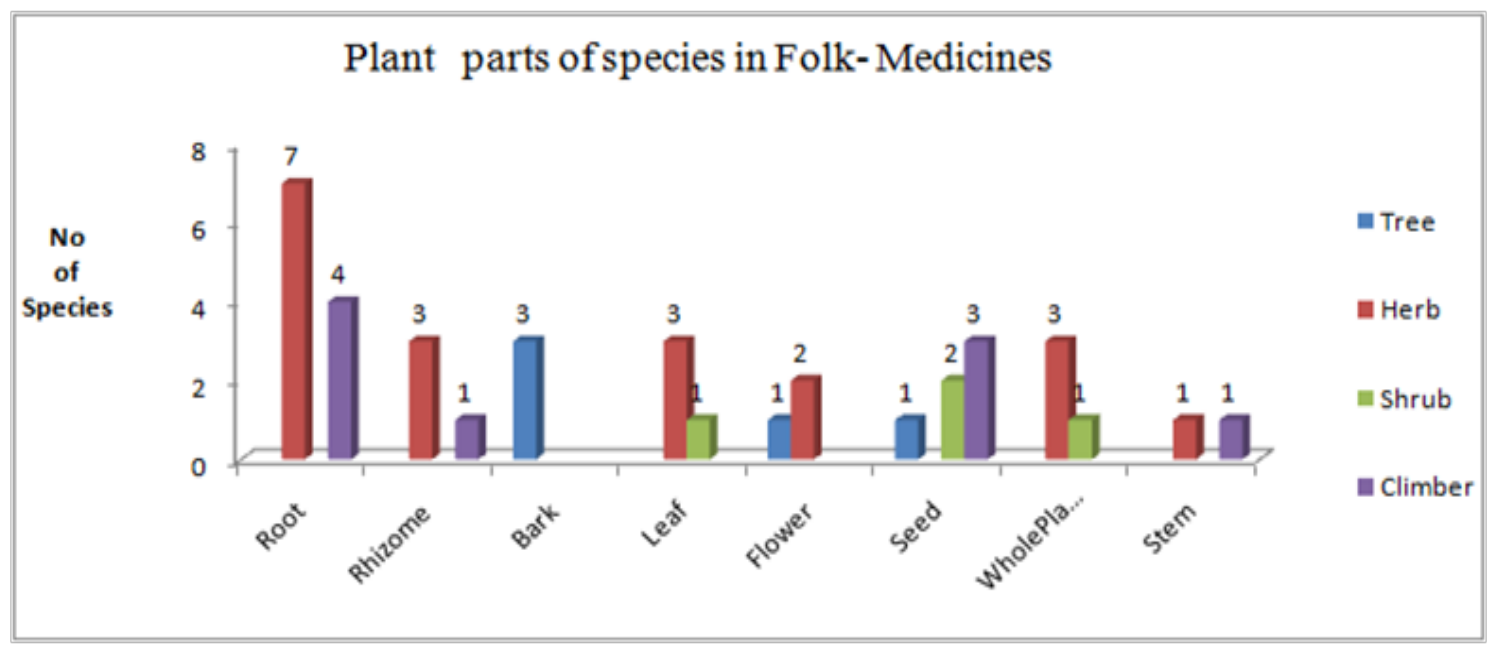

Figure 2 Plant parts of species prevalent in Folk-Medicines.

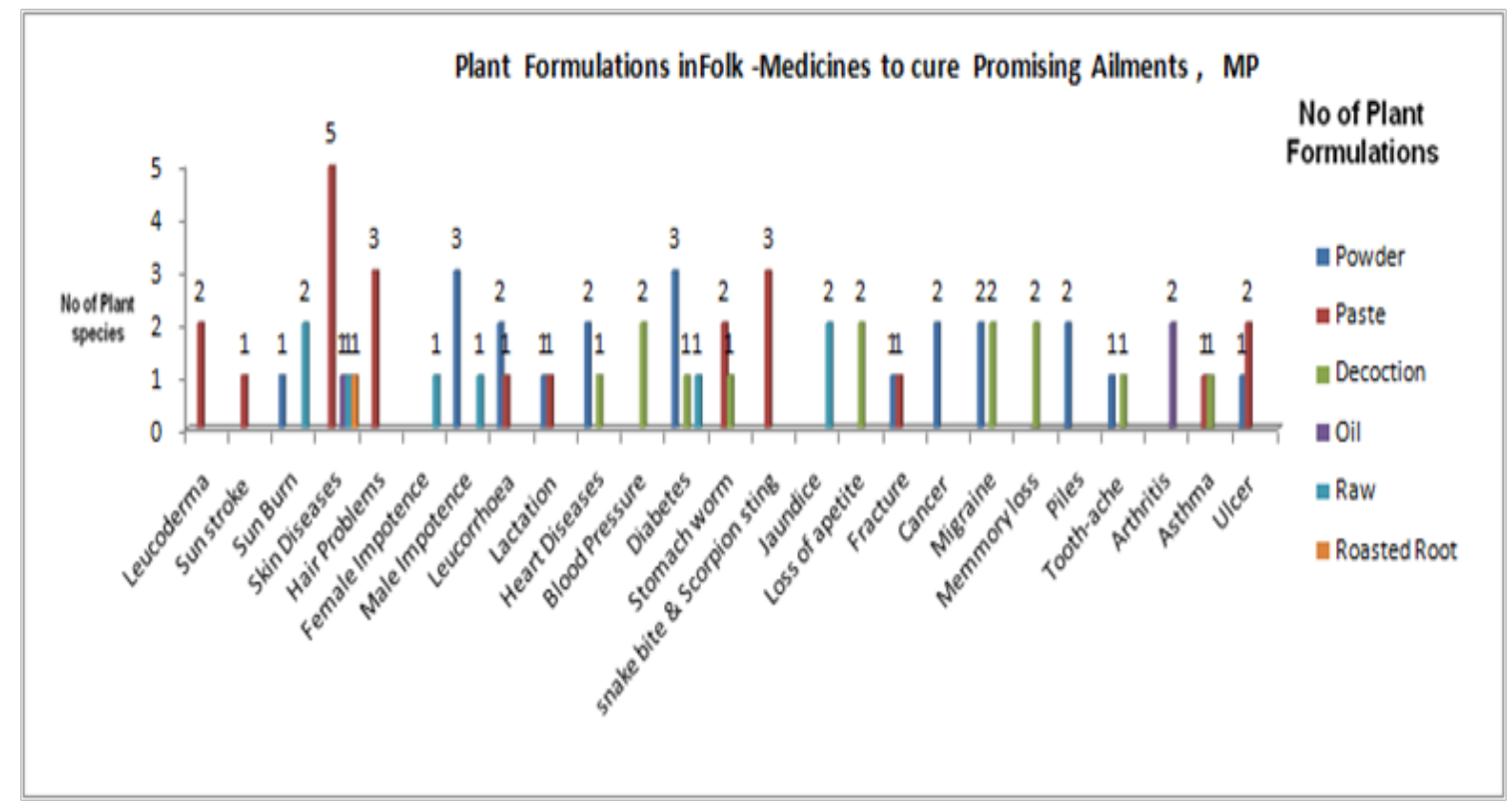

Figure 3 Plant formulations in folk medicines to cure promising ailments in Madhya Pradesh. 


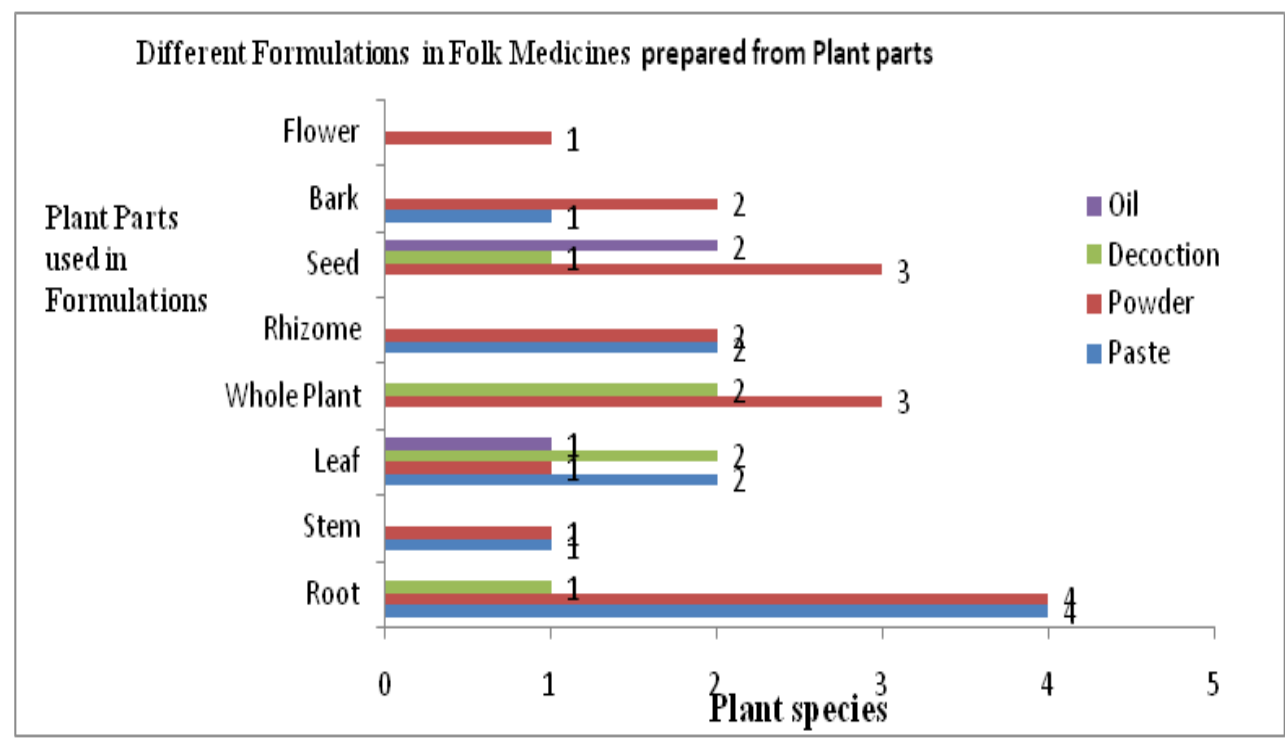

Figure 4 Different formulations in folk medicines prepared from plant parts.

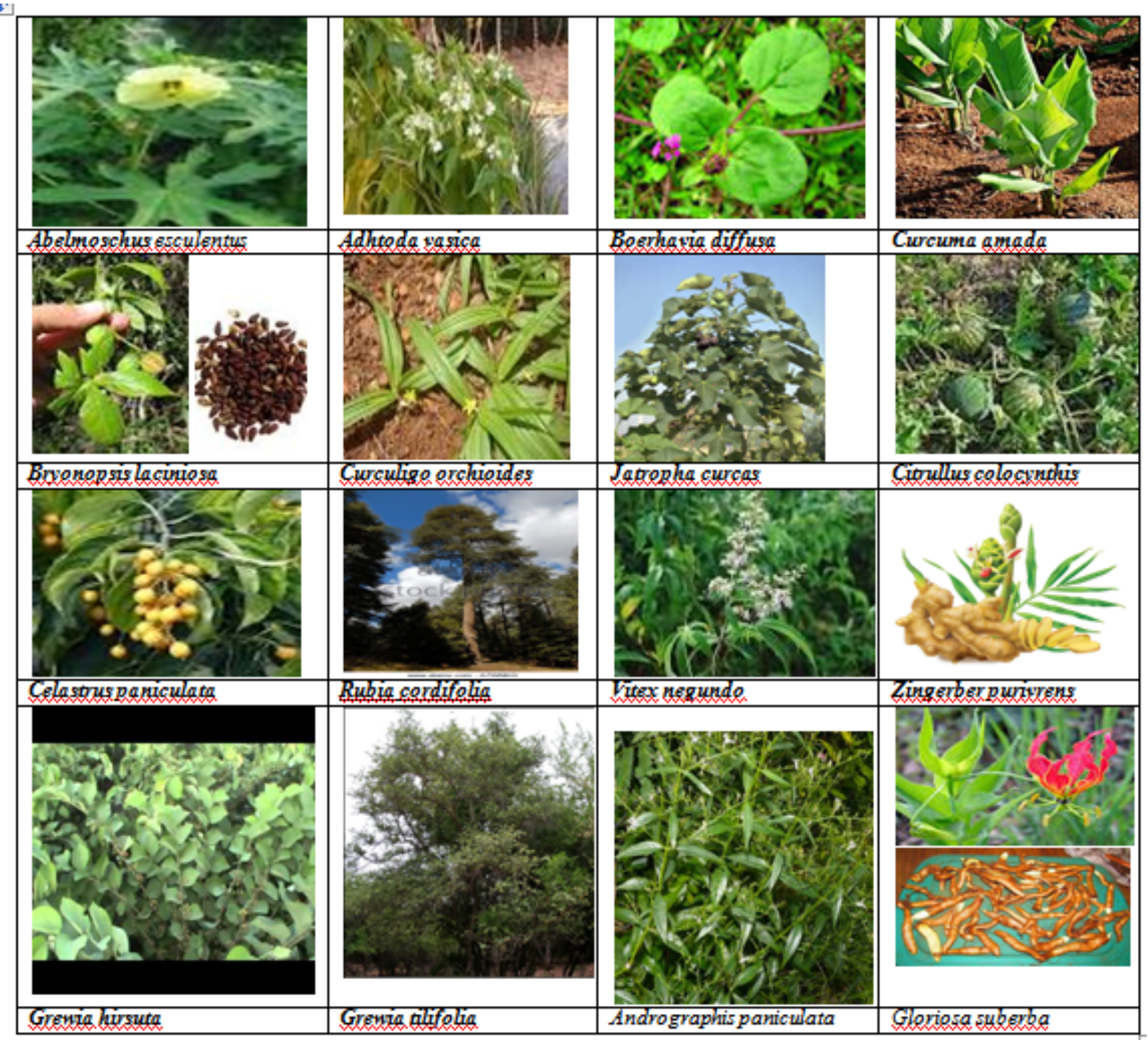

Figure 5 Some of the promising plants used in folk-medicines in Madhya Pradesh. 


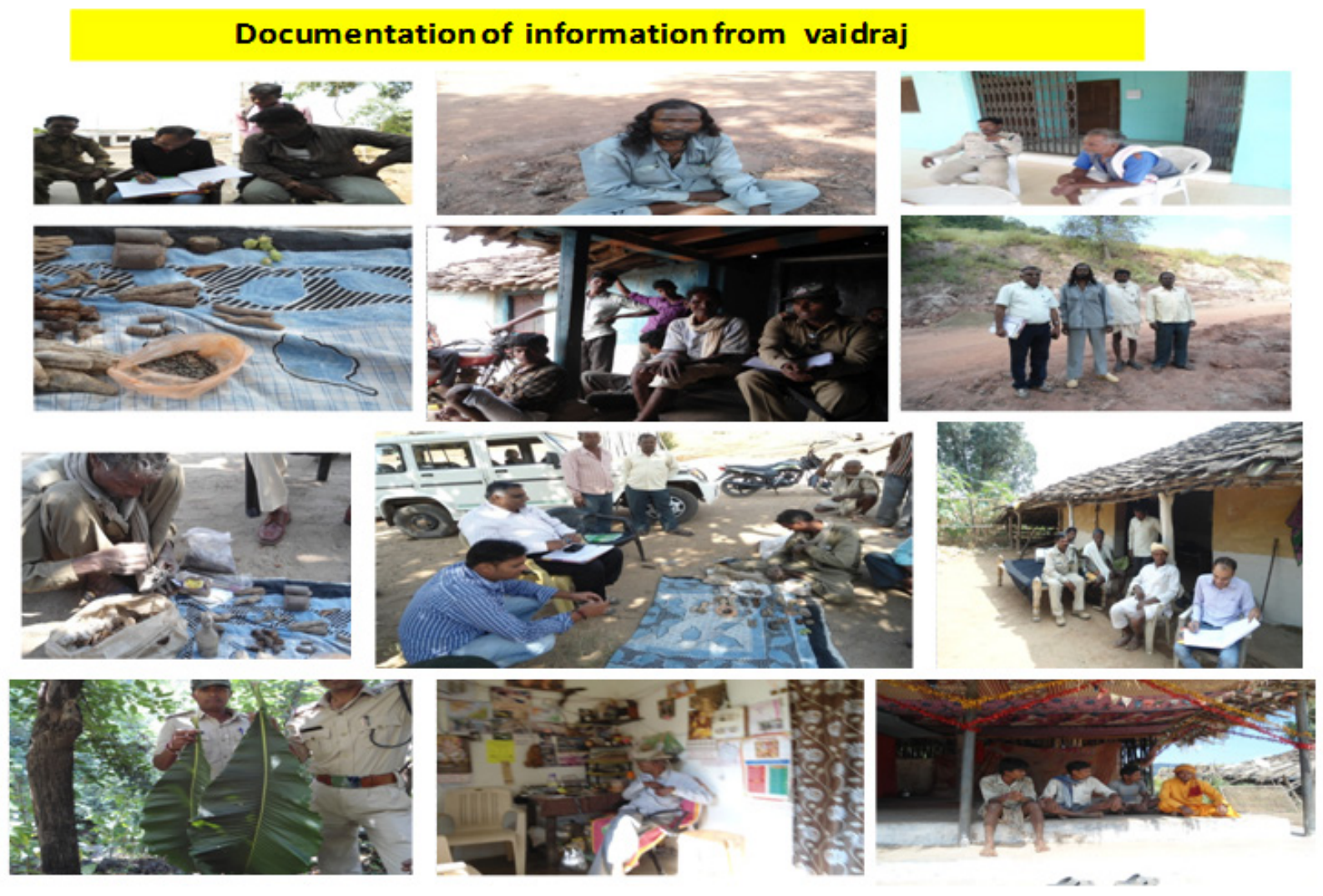

Figure 6 Documentation of folk medicines in Madhya Pradesh.

\section{Conclusion}

The indigenous knowledge system of herbal practice is still very rich and available among tribal community of Madhya Pradesh. The establishment of modern medicinal health centres is in progress in many rural areas that may gradually change the existing pattern of indigenous knowledge system of health care. Hence it is necessary to document the traditional knowledge of useful plants and their therapeutic uses before being lost forever from the community.

\section{Recommendation}

Plants documented in the study needs to be examined for phytochemical studies to know active principle component present in them which are beneficial in cure of ailments as recorded during study and presented. The investigation can lead to formulation of new drugs by pharmacological companies for benefit of mankind.

\section{Acknowledgements}

The author is thankful to traditional healers of ethnic communities for sharing the information on plants used in folk-medicines in Madhya Pradesh. The author is thankful to Director, Tropical Forest Research Institute, Jabalpur for providing facilities and author is also thankful to Director General, M P Council of Science and Technology, Bhopal for providing financial assistance for conducting the study.

\section{Conflict of interest}

Author declares that there is no conflict of interest.

\section{References}

1 Jain SK. Ethnobotany and Research on medicinal plants in India. Ethnoboany and Research on New Drugs. 1994:25-41.

2 Gupta R, Chadha KL. Medicinal and Aromatic Plants in India. In: Advances in Horticulture, Medicinal and Aromatic Plants Malhotra Publishing House, India; 1995:1-44.

3 Kala CP. Ethnomedicinal botany of the Apatani in the Eastern Himalaya region of India. J Ethnobiol Ethnomed. 2005;1(11):1-12

4 Jagtap SD, Deokule SS, Bhosle SV. Some unique ethnomedicinal uses of plants used by the Korku tribe of Amravati district of Maharashtra, India. J Ethnopharmacol. 2006;107(3):463-469

5 Nag R, Hambrick DC, Chen M. What is strategic management, really? Inductive derivation of a consensus definition of the field. Strategic Management Journal. 2007;28(9):935-955.

6 Kala CP, Ratajc P. High altitude biodiversity of the Alps and the Himalayas: Ethnobotany, plant distribution and conservation perspective. Biodiversity and Conservation. 2012;21(4):1115-1126.

7 Jain AK, Wagh VV, Kadel C. Some ethno-medicinal plants species of Jhabua district, Madhya Pradesh. Indian journal of traditional knowledge. 2011;10(3):538-540.

8 Bhalla NP, Sahu TR, Mishra GP, et al. Traditional plant medicines of Sagar district, M.P. J of Eco and Taxono Botany. 1986;3(1):23-32.

9 Dwivedi SN, Singh H. Ethnobotany of Kols of Rewa Divison M.P. Sen Envir EPCO II, 1984:37-44.

10 Dubey PC, Khanna KK, Sikarwar RLS, et al. Vindhya ki Ausidiya Avem Durlabh Vanaspattiyan. Van Vibhag Anusandhan Avem Vistar Vritt Riva (Madhya Pradesh); 2008. 
11 Jain SK. Studies on Indian Ethnobotany. Plants used in medicine by tribals of M.P. Bull Reg Res Lab Jammu. 1962;1:126-129.

12 Jain SK. Studies in Indian Ethnobotany-Plants used in medicines by the tribals of Madhya Pradesh. Bull Regional Research Lab. 1963;2:126-129.

13 Jain SK. Observation on Ethnobotany of tribals of M.P. Vanyajati. 1963;11(4):177-187.

14 Jain SK. Medicinal plant lore of the tribals of Bastar. Economic Botany. $1965 ; 19(3): 236-250$

15 Jain SK. Glimpse of Indian Ethnobotany. India: Oxford \& IBH Pub; 1981.

16 Jain SK. Dictionary of Indian Folk Medicines and Ethnobotany. India: Deep Publications; 1991.

17 Maheshwari JK, Dwivedi RP. Ethnobotany of Abujhmarah tribe of Bastar District. J Ind Bot Sco. 1985;64:53-56.

18 Maheshwar JK. Ethnobotanical documentation of primitive tribes of Madhya Pradesh. J Eco Taxon Bot Additional series. 1996;12:206-213.

19 Oommachan M, Masih SK. Multifarious Uses of plants by the tribals of Bastar of Madhya Pradesh, Medicinal plants. Indian J Applied \& Pure Bio. 1987;2(2):55-63.

20 Sahu TR. Life support promising food plants among aboriginals of Bastar, India. In: S.K. Jain, editor. In: Ethnobiology in Human Welfare. India: Deep Publication; 1996:26-30.

21 Jayson EA. An ecological survey at Satpura National Park ,Pachmarhi and Bori sanctuaries, Madhya Pradesh. Indian Journal of Forestry. 1991;13(4):288-294.

22 Jain AK, Virale MG. Some Threatened Angiosperm Taxa of Chambal Eco-region. Phytotaxonomy. 2007;7:107-110.

23 Jain AK, Virale GM, Singh R. Folklore claims on some medicinal plants used by Bheel tribes of Guna district Madhya Pradesh. Indian Journal of Traditional knowledge. 2010;9(1):105-107.

24 Jain AK, Wagh VV, Kadel C. Some ethno-medicinal plants species of Jhabua district, Madhya Pradesh. Indian Journal Of Traditional Knowledge. 2011;10(3):538-540.

25 Rai Rajiv. Traditional Uses of Genus Curcuma in Folk Medicines prevalent in Central India. Indian J Trop Biodiv. 2006;14(2):153-159.

26 Rai Rajiv. Some Traditional Plants used in cold, cough \&Fever by Tribals of Bastar (Chhattisgarh). Indian Journal of Botanical Science. 2007;86(1\&2):27-36.

27 Rai Rajiv (2008) Indigenous ad Herbal Medicines Prevalent among Tribal Communities in Madhya Pradesh. Journal of Non-Timber Forest Products. 2008;15(3):183-191.

28 Rai Rajiv. Ethno-Medicinal Uses of Promising Plants in Various Formulations in Cure of Ailments in Chhindwara District, Madhya Pradesh. Pharmacy \& Pharmacology International Journal. 2016;4(7):100.
29 Rai Rajiv. Folk Medicines in cure of ailments prevalent among ethnic communities in Madhya Pradesh. XIX Commonwealth forestry Conference. 2017. 25p.

30 Rai Rajiv, Nath V, Shukla PK. Ethno-medicinal studies on Bhariya Tribes in Satpura plateau of Madhya Pradesh. Agriculturist. 2002;13(1\&2):109-114.

31 Rai Rajiv, Nath V, Shukla PK. Ethnobiology of Hill Korwa Tribes. Journal of Tropical Forestry. 2003;19(1\&2):35-46.

32 Rai Rajiv, Nath V, Shukla PK. Characteristics and Ethnobotanical studies on Primitive tribes of Madhya Pradesh. In "Recent progress in Medicinal Plants", 'Ethno- medicine and Pharmacognosy'. India: Govils Publisher; 2004;8(37):543-552.

33 Rai Rajiv, Nath V. Ethnobotanical studies in Patalkot Valley in Chhindawara district of Madhya Pradesh. Journal of Tropical Forestry. 2004;20(2):38-50.

34 Mahajan SK. Traditional herbal remedies among the tribes of Bijagarh of West Nimar district, Madhya Pradesh. Indian Journal of Traditional Knowledge. 2007;6(2):375-377.

35 Kala CP. Aboriginal uses and management of ethnobotanical species in deciduous forests of Chhattisgarh state in India. Journal of Ethnobiology and Ethnomedicine. 2009;5:1-12.

36 Kala CP (2010) Home gardens and maganement of key species in the Pachmarhi Biosphere Reserve of India. International Journal of Medicinal and Aromatic Plants. 2010;1(2):153-161.

37 Srivastava JL, Jain Seema, Dubey Abhlasha. Ethno-medicine for anti-fertility used by tribals in Bastar district of Madhya Pradesh. In Ethnobotany and Medicinal Plants of Indian Sub-continent. India: Scientific Publisher; 2000. p. 297-300.

38 Shukla PK. Role of Research in sustainable and profitable management of NWFP. Vaniki Sandesh. 2004;28(2-3):1-4.

39 Satpathy KB, Panda PC. Medicinal use of some plants among tribals of Sundergarh district. J Econ Tax Bot Addl Series. 1992;10:241-249.

40 Wagh VV, Jain AK. Herbal remedies used by the tribal people of Jhabua district, Madhya Pradesh for the treatment of joint diseases. Inter $J$ of Phytotherapy. 2014;4(2):63-66.

41 Kadel C, Wagh VV, Jain AK. Some Ethno-medicinal plants of Jhabua district Madhya Pradesh. Indian Journal of Traditional Knowledge. 2011;10(3):538-540.

42 Patel P, Mahajan SK. A note on medico ethnobotany of Vijagharh (Khargone) Madhya Pradesh. Bull Bot Survey India. 2004;46(1-4):398-402.

43 Jadhav D, Rawat SS. Ethno-medicinal plants used in treatment of various ailments by Bhilala tribe of Alirajpur district Madhya Pradesh. $J$ Econ Taxon Bot. 2011;3(5):654-657.

44 Kumar R, Srivastava PN, Manju Jain. Ethnobotanical study of Traditional Medicinal plants used by tribes of Guna district. International Journal of Current Microbiology and Applied Sciences. 2015;4(7):466-471. 